\title{
Understanding Teacher Talk to Support Students' Communicative Competence
}

\author{
Hermanto
}

\begin{abstract}
Most people learn a foreign language in classrooms. Classroom language is the chief source of foreign language learning and in some places it is the only source. It functions not only as a major source of language learning but also as a tool by which a foreign language is taught. Based on the theory of second language acquisition (SLA), it is believed that the language that teachers address to L2 learners will to some degree influence language learning. Since a better understanding of the use of teachers' language can undoubtedly help students improve their learning, students can make a better use of teacher talk to learn the target language.
\end{abstract}

Key words: teacher talk, language learning, interaction, communicative competence

\section{Introduction}

For foreign language learners, classroom is the main place where they are frequently exposed to the target language. In the classroom, in trying to communicate with learners, teachers often simplify their speech, giving it many of the characteristics of foreigner talk and other simplified styles of speech addressed to language learners" (Richards, 1992: 471).

"Classroom process research has taken different forms: interaction analysis; teacher talk; discourse analysis" (Ellis, 1985:143). All dimensions of classroom process, from giving instruction to questioning or disciplining students, providing the feedback, involve teacher talk. Study on teacher talk has become one of the most important parts of classroom research.

As a critical part of classroom teaching, teacher talk did not arouse attention of academic field as early as the studies on teaching. A study on teacher talk owes much to the development of the branch of micro-teaching -- classroom research.

Classroom-centered research or classroom-originated research investigates the process of teaching and learning as they occur in classroom setting. "It simply tries to investigate what happens inside the classroom" (Allwright \& Baily, 1991:3). Its aim is to identify the phenomena that promote or hamper learning in the 
classroom.

The growth of interest in the analysis of teacher language has been stimulated by the rejection of language teaching method as the principal determinant of successful learning. At first, the underlying assumption in teaching had been finding the right method. It was believed that the teaching effect was completely determined by the choice of teaching method. Some studies investigated the comparative effectiveness of methods such as grammar-translation, audiolingualism, and cognitive code, but were not able to demonstrate that one was more successful than another (Ellis, 1985: 143). Despite the apparent differences in methodological principles, the various methods led to very similar patterns of classroom communication, with the result that the language learning outcomes were also similar.

\section{Classroom interaction and SLA}

A common theme underlying different methods of language teaching is that second language learning is a highly interactive process (Richards \& Lockhart, 2000:138). In recent years, a great deal of researches (Allwright, 1984; Ellis 1990; Long, 1983; Swain, 1985) in the field of L2 acquisition reveals to a great extent the importance of classroom interaction that involves both input and output. The Interaction Hypothesis claims that it is in the interaction process that acquisition occurs: learners acquire through talking with others (Johnson, 2002: 95). According to Allwright and Ellis, classroom teaching should be treated as interaction. Now it is clear that the language used in classroom affects the nature of the interaction, which in turn affects the opportunities available for learning, the study of interaction is therefore critical to the study of language classroom learning.

Van Lier (1988) points out: if the keys to learning are exposure to input and meaningful interaction with other speakers, we must find out what input and interaction the classroom can provide... we must study in detail the use of language in the classroom in order to see if and how learning comes about through the different ways of interaction in the classroom. He also pointed out that interaction is essential for language learning which occurs in and through 
participation in speech events, that is, talking to others, or making conversation (Van Lier, 1988:77-78).

In the following diagram, he suggests that interaction mediates between input and intake. Most important and central is the interaction with others in meaningful activities, but as a complement, and perhaps partial replacement, the learner's cognitive apparatus may also interact directly with the available input or sections.

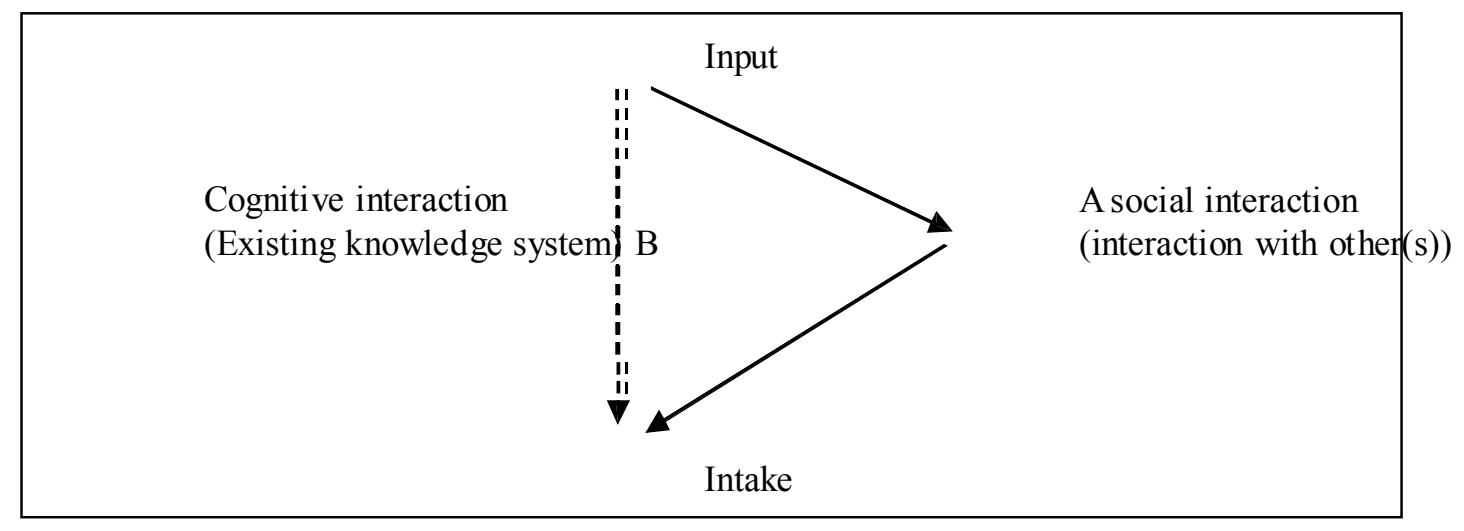

Figure 2.2 The role of interaction (Van Lier, 1988:93

Ellis (1985) points out: classroom instruction, both in the form of meaningful interaction, and in the form of linguistic rules, may influence the rate of acquisition. Teachers can influence the kind of interaction that occurs in their own classrooms. Successful outcomes may depend on the type of language used by the teacher and the type of interactions occurring in the classroom.

Fillmore (Ellis, 1985:160) is one of the researches to have investigated how classroom interaction affects the rate of SLA. Fillmore compared the progress of the sixty L2 learners in different classrooms. She found that neither the difference in classroom composition (mixed English-speaking and no-English speaking only) nor the difference in the type of teaching offered ('open' or 'teacher- 
directed') influences the success of language learning when considered separately. The availability of facilitative discourse types is not entirely dependent on the type of classroom organization adopted by the teacher. Pupils will learn most successfully when they are given ample opportunities to interact in conversation. So in this sense, we can say how a lesson progresses and whether it is successful largely depend on the interaction between the students and the teacher.

Classroom interaction is mainly realized by IRF (teachers' initiate-students' respond- teachers' feedback) structure. In this model, teachers often initiate interaction by asking questions. Teachers' questions not only can create more interaction activities, but can prompt students to participate in all kinds of negotiation of meaning. Negotiation makes input comprehensible and promotes SLA. The result of the negotiation of meaning is that particular types of input and interaction result (Ellis, 1985:142). Teachers carry out all his teaching tasks by teacher talk, an understanding of the aspects of teacher talk and their functions in the classroom interaction is, therefore, very important.

\section{The Definition of Teacher Talk}

The kind of language used by the teacher for instruction in the classroom is known as teacher talk (TT). For this term, Longman Dictionary of Language Teaching and Applied Linguistics defines it as "that variety of language sometimes used by teachers when they are in the process of teaching.

Rod Ellis (1985), after studying the SLA for many years, formulated his own view about teacher talk: "Teacher talk is the special language that teachers use when addressing L2 learners in the classroom." He also commented that "the language that teachers address to L2 learner is treated as a register, with its own specific formal and linguistics properties" (Ellis, 1985: 145).

From the definitions, firstly we can see that teacher talk in English classrooms is regarded as one special variety of the English language, so it has its own specific features which other varieties do not share. Secondly, we can see that teacher talk is a special communicative activity. Its goal is to communicate with 
students and develops students' foreign language proficiency.

Teacher talk is used in class when teachers are conducting instructions, cultivating their intellectual ability and managing classroom activities. Teachers adopt the target language to promote their communication with learners. In this way, learners practice the language by responding to what their teacher says. Besides, teachers use the language to encourage the communication between learners and themselves. Therefore we can say teacher talk is a kind of communication-based or interaction-based talk.

Teacher talk is particularly important to language teaching (Cook, 2000:144). According to pedagogical theory, the language that teachers use in classrooms determines to a larger degree whether a class will succeed or not. Many scholars found teacher talk makes up around $70 \%$ of classroom language (Cook, 2000; Chaudron, 1988).Teachers pass on knowledge and skills, organize teaching activities and help students practice through teacher talk. In English classrooms, teachers' language is not only the object of the course, but also the medium to achieve the teaching objective. Both the organization of the classroom and the goal of teaching are achieved through teacher talk.

\section{The role of $\mathrm{TT}$ in language classroom}

There is no learning without teaching. So as a tool of implementing teaching plans and achieving teaching goals, teacher talk plays a vital important role in language learning. Quite a few researches have discussed the relationship between teacher talk and language learning. As Nunan (1991) points out "Teacher talk is of crucial importance, not only for the organization of the classroom but also for the processes of acquisition. It is important for the organization and management of the classroom because it is through language that teachers either succeed or fail in implementing their teaching plans. In terms of acquisition, teacher talk is important because it is probably the major source of comprehensible target language input the learner is likely to receive." 
According to SLA theory, plenty of and high-quality input is the necessary element for successful language learning. There is no learning without input. "If the second language is learnt as a foreign language in a language class in a nonsupportive environment, instruction is likely to be the major or even the only source of target language input" (Stern, 1983:400). Here instruction refers to teacher instruction--teacher talk. Stern proposed a teaching-learning model which identified two principle actors, the language teacher and the language learner.

"The teacher, like the learner, brings to language teaching certain characteristics which may have bearing on educational treatment: age, sex, previous education, and personal qualities. Above all, the language teacher brings to it a language background and experience, professional training as a linguist and teacher, previous language teaching experience, and more or less formulated theoretical presuppositions about language, language learning and teaching” (Stern, 1983: 500). These characteristics of language teacher are reflected in different characteristics and forms of TT. Stern's teaching-learning model reveals the important role of the language teacher and teacher talk during the process of language learning.

\section{The features of Teacher Talk}

Long (1983b), Long \& Sato (1983) observed all kinds of phenomena about teacher talk, and made some comparison between the language that teachers use in and out of language classrooms. Their main findings are as follows:

1) Formal adjustments occur at all language levels.

2) In general, ungrammatical speech modifications do not occur.

3) Interactional adjustments occur. (Ellis, 1985:145).

Long and Freeman (2000) found that teacher talk is simplified in other ways- syntactically, phonologically and semantically. In the syntactic domain, utterance length to children is shorter. In the area of phonology, speech to children is pitched higher, has more exaggerated intonation, and uses a wider pitch range. It's characterized by clearer articulation, pauses between utterances and an overall slower rate of delivery. In the semantic domain, vocabulary is more restricted, teachers carefully select the words they use according to the students proficiency 
and level. New words and difficult words are avoided.

Chaudron (1988: 85), having investigated teacher talk for a long time and summarized some research results on teacher talk, proposed teacher talk in language classrooms tends to show the following modifications:

1) Rate of speech appears to be slower.

2) Pauses are possibly more frequent and longer.

3) Pronunciation tends to be exaggerated and simplified.

4) Vocabulary use is more basic.

5) Degree of subordination is slower.

6) More declaratives and statements are used than questions.

7) Teachers may self-repeat more frequently.

\section{The amount of Teacher Talk}

According to second language acquisition theories, both teachers and students should participate in language classes actively. Teachers have to face two tasks in language classrooms: 1) offer enough high-quality English language input; 2) offer more opportunities for students to use the target language. So the distribution of teacher talk time, as an important factor that affect language learning, has been concerned by many scholars.

An important issue is whether the amount of teacher talk influences learners' L2 acquisition or foreign language learning. A great number of researchers have testified this. Researches in language classrooms have established that teachers tend to do most of the classroom talk. Teacher talk makes up over 70 percent of the total talk. (Cook, 2000; Legarreta, 1977; Chaudron, 1988) It is evident that if teachers devote large amounts of time to explanations or management instructions, student talk will be indeed severely restricted. Teacher-initiated talk will dominate the classroom, allowing little opportunity for extended student talk. In such an environment, students have little opportunity to develop their language proficiency. In order to avoid the over- use of teacher talk, many scholars tend to maximize student talk time (STT) and minimize teacher talk time (TTT). Harmer (2000: 4) points out that the best lessons are ones where STT is maximized. Getting students 
to speak -- to use the language they are learning--is a vital part of a teacher's job.

American scholar Wong-Fillmore put forward her finding that is different from others' after observing primary language classrooms for three years. She found all the success in SLA occurred in teacher-dominated classes. In contrast, little SLA took place in classes with too much interaction among students. Fillmore explained these results in terms of the type of input which was received in the different classrooms. In successful classrooms the teachers serve as the main source of input, the learners can receive enough and accurate input. However in student-centered classrooms, the pupils did not receive so much teacher input, and tended to use the L1 when talking among themselves. Therefore, Fillmore argued the amount of TT should not be decreased blindly. If do so, she suggested two conditions to ensure successful SLA in classrooms from the 40 classes she investigated: one is the students must have high-level language proficiency so that they can communicate with their teacher and among themselves; the other is there must be enough students who want to communicate in class. If the two conditions do not exist in classrooms, the decrease of teacher talk time won't lead to successful language learning.

\section{Teachers' questions}

Questioning is one of the most common techniques used by teachers (Jack C. Richards \& Charles Lockhart, 2000) and serves as the principal way in which teachers control the classroom interaction. The tendency for teachers to ask many questions has been observed in many investigations (Chaudron, 1988). In some classrooms over half of class time is taken up by question-and-answer exchanges (Richards \& Charles Lockhart, 2000). Teachers' questions have attracted considerable attention from researchers of language classroom.

\section{Functions of teachers' questions}

The pervasiveness of teacher questions in the classroom can be explained by the specific functions they perform. These functions can be grouped into three broad areas: diagnostic, instructional, and motivational (Donald, K \& Paul D. Eggen, 1989). 
As a diagnostic tool, classroom questions allow the teacher to glimpse into the minds of students to find out not only what they know or don't know but also how they think about a topic. Recent research on schema theory suggests that the structure of students' existing knowledge is a powerful determinant of how new information will be learned, and that often student misconceptions and prior beliefs interfere with the learning of new material (Donald, K \& Paul D. Eggen, 1989). Through strategic questioning, the teacher can assess the current state of student thinking, identifying not only what students know but also gaps and misconceptions.

A second important function that questions perform is instructional. The instructional function focuses on the role that questions play in helping students learn new material and integrate it with the old one. Questions provide the practice and feedback essential for the development. Questions alert students to the information in a lesson. Questions are also valuable in the learning of integrated bodies of knowledge. Toward this goal, questions can be used to review previously learned material to establish a knowledge base for the new material to be learned. In addition, as the new material is being developed, questions can be used to clarify relationships within the content being discussed.

A third function that classroom questions perform is motivational. Through questions teachers can engage students actively in the lesson at hand, challenging their thinking and posing problems for them to consider. From a lesson perspective, a question at the beginning can be used to capture students' attention and provide a focus for the lesson. In addition, frequent and periodic questions can encourage active participation and provide opportunities in the lesson for continued student involvement. Research in this area shows student on-task behaviors are highest during teacher-led questioning sessions. Finally, at the individual level, questions can be used to draw wandering students back into the lesson or to provide an opportunity for one student to "shine".

\section{The types of teacher's questions}

Most of the researches on teachers' question focus on the classification of it. 
There are many different ways to classify questions. Barnes examined the questions asked by teachers and classified the questions into four types. The first type is questions concerning factual matters, that is, the questions beginning with "what". The second type is questions of inference beginning with "how" and "why". The third type is open questions which do not require any inference. The last type is questions for communication, which could affect and control the behavior of learners. Barns further classified the second type into closed questions and open questions. Questions are closed because there is only one existing answer, while open questions there are more than one answer. Barnes also stressed that some questions seemed open, but the answers were closed.

Jack C. Richards \& Charles Lockhart (2000) classify the questions into three categories in terms of the purpose of questions in classrooms -- procedural, convergent, and divergent. Procedural questions have to do with classroom procedures and routines and classroom management. They are used to ensure the smooth flow of the teaching process. Unlike procedural questions, many of the questions teachers ask, such as convergent and divergent questions, are designed to engage students in the content of the lesson, to facilitate their comprehension, and to promote classroom interaction. Convergent questions encourage similar student responses, or responses which focus on a central theme. These responses are often short answers, such as "yes" or "no" or short statements. They do not usually require students to engage in high-level thinking in order to come up with a response but often focus on the recall of previously presented information. Divergent questions are quite different from convergent questions. These questions encourage diverse student responses which are not short answers and which require students to engage in higher-level thinking. They encourage students to provide their own information rather than recall previously presented information.

With the growth in concern for communication in language classrooms, a further distinction has been made between "display" and "referential" questions by Long and Sato (1983). Display questions refer to ones that teachers know the answer 
and which are designed to elicit or display particular structures. For example, 'what's the opposite of up in English?' On the contrary, referential questions refer to the questions that teachers do not know the answers to, and can gain various subjective information. For example, 'Why don't you do your homework?' Because closed questions and convergent questions have the same feature as referential questions, they are regarded as the same type of questions; so are open questions and divergent questions.

It has often been observed that teachers tend to ask more display questions than referential questions (Long \& Sato, 1983; Pica \& Long, cited from Ellis, 1994). The explanation for this by Barnes is the role the teachers play. If the teachers just pass on information rather than encourage students to participate in classroom activities, they tend to ask referential question. However, Long \& Sato conclude that is because the teachers emphasized much more on the form and accuracy of the language, instead of the meaning of language and communication. It must be pointed out that all their researches were conducted in teacher-dominated classrooms. In student-centered language classrooms, proportionately more referential questions were asked than display.

\section{Teacher's feedback}

Providing feedback to learners on their performance is another important aspect of teaching. Feedback is teachers' evaluation of the student response (Cook, 2000). Feedback can be either positive or negative and may serve not only to let learners know how well they have performed but also to increase motivation and build a supportive classroom climate. In language classrooms, feedback on a student's spoken language may be a response either to the content of what a student has produced or to the form of an utterance. Feedback can be given by means of praise, by any relevant comment or action, or by silence (Richards, J. \& Lockhart, 2000).

Wheldall and Merrett (1987) cite a large number of studies showing that rewards, such as praise, are far more effective than punishment. The evidence on 
punishments tends to reveal that not only are they ineffective in bringing about positive change, but they can often have the opposite effect. Therefore, they have even built an approach to teaching based on this Principle which they term 'Positive Teaching' and which they claim to be highly effective (Wheldall and Merrett, 1984).

Most theorists and practitioners agree that favorable feedback about performance has a positive effect on subsequent performance. Knowledge of poor results for some children could be devastating, so we should try to strike at the right level with each child to ensure high success rates. Nevertheless, we should avoid the fallacy of trying to pretend that a child's performance is good when it is not. This only leads to low personal standards. By insisting on realistic goals and thus ensuring some measure of success for each child, we are increasing the likelihood of reinforcement.

Therefore, teachers' feedback plays a significant part in an individual's motivation. Besides, it should be emphasized here that the potentially negative effects of rewards and praise are more likely to occur when extrinsic motivators are superfluous and unnecessary.

Feedback has two main distinguishable components: Correction and assessment (Ur, 2000: 242).

\section{Teacher's Correction}

Inevitably learners will make mistakes in the process of learning. "A learner's errors... are significant in (that) they provide to the researcher evidence of how language is learned or acquired, what strategies or procedures the learner is employing in the discovery of the language (Brown, 2002: 205)." It is a vital part of the teacher's role to point out students' mistakes and provide correction. In correction, some specific information is provided on aspects of the learners' performance, through explanation, or provision of better or other alternatives, or through elicitation of these from the leaner (Ur, 2000). Correction helps students to clarify their understanding of meaning and construction of the language.

One of the crucial issues is how correction is expressed: gently or 
assertively, supportively or as a condemnation, tactfully or rudely. Ur (2000) points out that we should go for encouraging, tactful correction. The learner has reliable intuitive knowledge about what kind of correction helps most, that is, learner preferences are on the whole a reliable guide. So teachers have to be careful when correcting, if teachers do it in an insensitive way, the students will feel upset and lose their confidence. What kind of correction teachers think is best and learners find most useful? A good deal of teacher sensitivity is needed here. Generally, the teachers always adopt the following techniques to correct students' errors (Ur, 2000:249):

1) Does not react at all.

2) Indicates there is a mistake, but does not provide any further information about what is wrong.

3) Says what was wrong and provides a model of the acceptable version. That is -- explicit correction.

4) Indicates something was wrong, elicits acceptable version from the learner who made the mistake (Self-repair).

5) Indicates something is wrong, elicits acceptable version from another member of the class.

6) Ask the learner who made the mistake to reproduce the corrected version.

7) Provides or elicits an explanation of why the mistake was made and how to avoid it.

Furthermore, it is worth pointing out that it is just as important to praise students for their success, as it is to correct them when they fail. Teachers can show their praise through the use of encouraging words and noises ('good', 'well done', 'fantastic', 'mmm,' etc.) when students are doing really well (Harmer, 2000).

\section{Teacher's Assessment}

Assessment refers to the tools, techniques and procedures for collecting and interpreting information about what learners can and cannot do (Nunan, 1991). In assessment, the learner is simply informed how well or badly he or she has performed. A percentage grade on an exam would be one example; or the 
response "No" to an attempted answer to a question in EFL classroom; or a comment such as "Excellent" at the end of a written assignment (Ur, 2000). Whenever teachers give assessment on the students, we should not forget that the purpose is to help and promote EFL learning. Therefore, teacher's talk should be full of approval and encouragement besides confirmation. The following lists some words and phrases when teachers evaluate students' performance.

\section{Confirmation}

1) Good

Right; yes; fine; you are right; that is correct; you have got it.

2) Excellent

Very good; terrific; well done; good work; marvelous; you did a very good job.

3) That is perfectly correct

There is nothing wrong with your answer; what you said is right; that is exactly the point; I couldn't have given a better answer myself.

4) No, that is wrong

Not really; unfortunately not; I am afraid that is not quite right; you cannot say that, I am afraid; you cannot use that; not quite right.

\section{Encouragement}

1) That is better

That is much better; that is more like it; you have improved a little; you have very good pronunciation; you read fluently; you have made a lot of progress; you are getting better.

2) Try it again

Try again; have another try; you were almost right that time; almost right; not exactly; you have almost got it; take it easy; there is no need to hurry; go on; have a guess if you don't know; maybe this will help you; well, err....

3) Don't worry 
Don't worry about ...; I'll help you; maybe this will help you.

The following grumbles should be avoided as much as possible in EFL classroom.

1) That wasn't very good

That was rather disappointing; that wasn't up to much; I am not satisfied with that; that is awful/ terrible.

2) You can do better than that

Can't you do better than that; when you try this again, I expect you to...; the next time you do this, I want you all to...; this is the last time I shall tell you.

3) You fool

Idiot; you stupid idiot; I have never heard anything so ridiculous; what a load of rubbish.

It is clearly up to teachers to decide what kind of phrases are appropriate. Expressions of joy, sympathy, surprise, interest, etc., may also be equally effective. Teachers should employ as much approval and encouragement as possible in foreign language classrooms, which will be conducive to the development of the students' positive affect and the foreign language learning.

\section{Conclusion}

All of the above theories reveal the effects of different types of classroom interaction on L2 acquisition from different perspectives. Therefore, a conclusion can be drawn from these theories, that is, a foreign language classroom that can facilitate learners' language learning should have the following features, first, providing opportunities for learners to communicate in the target language and enable them to learn the target language through meaningful use of it; second, providing optimal comprehensible input for learners through classroom communication. Both teachers and learners make an effort to make their speech comprehended by using communicative strategies; third, negotiation of meaning is encouraged. Teachers are expected to initiate learners to reorganize their language by using interactional modifications when problems occur in communication.

Then, do the classrooms under the investigation have the features presented 
above? Teacher talk is not only the tool that teachers use to impart knowledge, but the most important means to control the classroom. The research on teacher talk provides us with an ideal perspective to investigate and understand what is really going on in EFL classrooms.

\section{References}

Allwright, D. \& Bailey, K. 1991. Focus on the Language Classroom. Cambridge: Cambridge University Press.

Brown, H. D. 2000. Principles of Language Learning and Teaching (3 ${ }^{\text {rd }}$ Edition). Cambridge: Cambridge University Press.

Barnes, D.1969. Language in the Secondary Classroom. In D. Barnes et al. (eds.) Language, the Learner and the School. Harmondsworth: Penguin.

Chaudron, C. 1988. Second Language Classrooms: Research on Teaching and Learning. Cambridge: Cambridge University Press.

Cook, V. 2000. Second Language Learning and Language Teaching (2 ${ }^{\text {nd }}$ Edition). Cambridge: Cambridge University Press.

Donald, K \& Paul D. Eggen. 1989. Learning and Teaching: Reaearch based Methods.

Ellis, R. 1985. Understanding Second Language Acquisition. Cambridge: Cambridge University Press.

Ellis, R. 1994. The Study of Second Language Acquisition. Cambridge: Cambridge University Press.

Johnson Keith. 2002. An Introduction to Foreign Language Learning and Teaching. Cambridge: Cambridge University Press.

Harmer, J. 2000. How to Teach English. Cambridge: Cambridge University Press.

Larsen-Freeman, D.\& Long, M. 2000. An Introduction to Second Language Acquisition Research. Cambridge: Cambridge University Press.

Long, M \& Sato, C. 1983. Classroom Foreigner Talk Discourse: Forms and Functions of Teachers' questions. In Seliger and Long (eds.) Classroom Oriented Research in Second Language Acquisition. Newbury House. 
Long, M. 1983b. Native speaker/non-native speaker conversation in the second language classroom. On TESOL'82: Pacific Perspectives on Language Learning and Teaching. Washington, D.C.: TESOL.

Nunan, David. 1991. Language Teaching Methodology: a textbook for Teachers. Cambridge: Cambridge University Press.

Richards, J.\& Lockhart, C. 1994. Reflective Teaching in Second Language Classrooms. Cambridge: Cambridge University Press.

Richards, J. C. 1992. Longman Dictionary of Language teaching \& Applied linguistics. Cambridge: Cambridge University Press.

Stern, H.H. 1983. Fundamental Concepts of Language Teaching. Cambridge: Cambridge University Press.

Strong, M. 1983. Motivating Analysis of Exchange Structure. In M. Coulthard and M. Swain, M. 1985. Communicative competence: some roles of comprehensible input and comprehensible output in its development. In S. Gass \& C. Madden (eds.). Input in Second Language Acquisition. Rowley, Mass.: Newbury House.

Ur Penny. 2000. A Course in Language Teaching Practice and Theory. Cambridge: Cambridge University Press.

Van Lier, L. 1988. The Classroom and the Language Learner. London: Longman. Weinstein, C. S. 1989. Teacher Education Students' Perceptions of Teaching. Journal of Teacher Education.

Wheldall, K. \& F. Merrett. 1987. What is the Behavioral Approach to Teaching? In N. Hastings and J. Ackwieso (Eds.) New Directions in Educational Psychology (Vol. 2), Behavior and Motivation. Brighton: Falmer Press.

Wheldall, K. \& F. Merrett. 1984. Positive Teaching: The Behavioral Approach. London: Allen and Unwin. 